\title{
Review
}

\section{The Environmental Millennium Development Goal: progress and barriers to its achievement}

\author{
Lucas Donat Castelló ${ }^{a, b, *}$, Diana Gil-González ${ }^{c}$, Carlos Alvarez-Dardet Diaz ${ }^{b, c}$, \\ Ildefonso Hernández-Aguado ${ }^{a, b}$ \\ a Department of Public Health, History of Science and Gynaecology, Miguel Hernandez University, Ctra. Valencia km 8.7, \\ 03550 San Juan de Alicante, Spain \\ ${ }^{\mathrm{b}}$ CIBER of Epidemiology and Public Health (CIBERESP), Spain \\ ${ }^{\mathrm{c}}$ Department of Community Nursing, Preventive Medicine, Public Health and History of Science, University of Alicante, \\ Campus San Vicente del Raspeig, Ap-99, E-03080 Alicante, Spain
}

\section{A R T I C L E I N F O}

Keywords:

Millennium Development Goals

Environmental sustainability

Progress

Knowledge

Systematic review

\begin{abstract}
A B S T R A C T
Ensuring environmental sustainability is the aim of the seventh Millennium Development Goal (MDG7). United Nations data shows insufficient progress, especially in developing countries. In order to generate new information about this progress and the main barriers that hinder it, we conducted a systematic review to describe the scientific evidence concerning MDG7, and to analyse the quality of the studies. In order to identify all empirical quantitative studies (ecological, descriptive study, cross-sectional, case-control, and cohort), we searched the following databases between 23 and 26 June 2009: PubMed, EMBASE, ISI WoK, SCOPUS, EBSCO-Greenfile, CAB Abstracts, and LILACS. We identified six empirical studies which reported serious difficulties in the progress of MDG7 and identified socioeconomic inequalities, lack of infrastructure and contamination of water sources as the main barriers hindering its achievement.

Environmental issues do not seem to be a priority in research and political agendas, while the international organisations continue to insist that the objective is extremely important. It is necessary to generate scientific knowledge around MDG7, and identify weakness in the indicators in order to adapt policies to the new challenges and make decisions based in best evidence.
\end{abstract}

(C) 2009 Elsevier Ltd. All rights reserved.

\section{Introduction}

The Millennium Development Goals (MDG) were established in the year 2000, in the United Nations Millennium Declaration, with the support of 191 member states and constituted a significant institutional agreement for a global strategy to achieve the basic conditions for development, health and welfare (United Nations, 2000a,b). Ensuring environmental sustainability is the aim of the seventh Millennium Development Goal (MDG7), and includes Target 9, refers to integrate sustainable development into the policies and reverse the loss of environmental resources, Target 10 , refers to halve the

* Corresponding author at: Department of Public Health, History of Science and Gynaecology, Miguel Hernandez University, Ctra. Valencia km 8.7, 03550 San Juan de Alicante, Spain. Tel.: +34 965 919516; fax: +34 965919551.

E-mail address: ldonat@umh.es (L. Donat Castelló).

1462-9011/\$ - see front matter (C) 2009 Elsevier Ltd. All rights reserved.

doi:10.1016/j.envsci.2009.12.001 
proportion of population without access to safe water and basic sanitation, and Target 11, refers to improve living conditions of slums dwellers. In the preceding years, there were other international initiatives which drew attention to global environmental issues and the importance of sustainability on population health. These included The Earth's Summit in Rio de Janeiro (United Nations Conference on Environment and Development, 1992) and the Kyoto protocol agreements (United Nations Framework Convention on Climate Change, 1997).

The integration of environmental issues into population health frameworks is now widely accepted and can been seen in Dahlgren and Whitehead's 'rainbow model' of the social determinants of health (Dahlgren and Whitehead, 2007). In this model, environmental conditions interact with the socioeconomic and cultural context, with working and living conditions, and influence population health. Other authors have stated that sustainable population health depends on the viability of the planet's life-support systems (McMichael et al., 2003), and investments in environmental sustainability policies are necessary to reduce poverty and inequalities (Sachs and Reid, 2006). Furthermore, in the MDG strategy, environmental sustainability directly influences other MDG, such as the eradication of hunger, the reduction in infant mortality, the improvement of maternal health and the fight against infectious diseases (Melnick et al., 2005; McMichael and Butler, 2006; Anyangwe et al., 2006; Prüss et al., 2002; Varis, 2007).

Given the effects of climatic change, environmental sustainability is currently a priority in the agenda of many governments in developed countries. Nevertheless, it is developing countries who face the greatest challenges in achieving the Environmental Millennium Development Goal's targets, and predictive models presented in some papers show the situation worsening in the forthcoming decades (Sahn and Stifel, 2003; Chakravarty and Majumder, 2008; Agénor et al., 2006).

An annual report made by The United Nations which monitors the progress of the MDG (United Nations, 2000a,b) shows that the situation of the MDG7 is not very promising especially for countries with greater socioeconomic problems (United Nations, 2009); the number of people who continue to use solid fuel in developing countries is increasing, the forest mass is still decreasing at a rate of about 13 million hectares per year, and although the percentage of people without access to drinking water and basic sanitation facilities is falling, it does so too slowly, especially in the poorest countries. Furthermore, although the number of people living in slum conditions is declining (United Nations, 2009), the rapid expansion of towns and the mass exodus towards urban and peri-urban areas, are causing an increase in the number of settlements without basic sanitation and health conditions (Satterthwaite, 2003; Varis, 2006).

Although the information collected by the UN reflects the inequalities among countries in terms of the progress of the MDG, more information is required in order to identify the barriers which hinder the progress of the MDG (Gil-González et al., 2008). Increasing scientific knowledge about the situation of MDG7 and its targets should complement the information in the annual reports of international organisations, and help identify the determinants which act as obstacles to the progress of this goal. In addition, the use of systematic methods to review the evidence should help public and environmental institutions develop evidence based policies.

Consequently, this study aims to describe the scientific evidence concerning the progress of the Millennium Development Goal 7, to identify the barriers which could hinder its achievement, and to analyse the quality of the empirical studies in this area.

\section{Materials and methods}

A systematic review was carried out of all empirical studies whose primary aim was (1) to describe the situation of the Millennium Development Goal 7 or one of its targets, and (2) to analyse the barriers which hinder their progress.

\subsection{Eligibility criteria}

For the purposes of this review, two types of studies were included.

First, we selected all empirical quantitative studies like: ecological, case study, cross-sectional designs and which describe the state of progress of the Millennium Development Goal 7 or one of its targets, in any country or region.

Secondly, we included all empirical quantitative studies which designs were: ecological, case study, cross-sectional, case-control, cohort that identified and analysed potential barriers (economic, political, social, cultural, and geographical) which could hinder the attainment of the Millennium Development Goal 7 or any of its targets.

Studies which addressed environmental problems without any specific reference to the Millennium Development Goals were excluded because our main objective was to explore the progress and barriers in the achievement of this specific goal. Those concerning interventions to improve the environment, and those which set out to analyse other MDGs using MDG7 indicators were also excluded.

\subsection{Search strategy}

We searched seven environmental, health and multidisciplinary electronic databases for documents of any type, from any country, available in English or Spanish, and published between 2000 and 2008. The decision to include only studies published on or after the year 2000 was made because this was the year that the Millennium Development Goals agreement was signed. Details of the databases searched and the search terms are shown in Box 1. The search strategy used text words rather than Medical Subject Headings because this tool is only available in one of the databases (PubMed), and because of the multidisciplinary nature of the topic.

In order to explore all possible sources of information, we also searched the reference section of the included studies, and we performed a hand-search of four of the most relevant journals restricted to 2007, 2008 and 2009. These journals were "Environmental Health Perspectives" (United States National Institute Environmental Health Sciences), "Global Environmental Change -Human and Policy Dimensions- "(Elsevier), 


\section{BOX 1. SEARCH STRATEGY OF PAPERS RELATED TO MDG7.}

\begin{tabular}{|c|c|c|c|c|c|c|c|}
\hline \multirow[t]{2}{*}{ Search terms } & \multicolumn{7}{|c|}{ Databases } \\
\hline & $\begin{array}{l}\text { PubMed* } \\
(23-6-2009)\end{array}$ & $\begin{array}{l}\text { EMBASE* } \\
(23-6-09)\end{array}$ & $\begin{array}{l}\text { ISI Web of } \\
\text { Knowledge* } \\
(23-6-2009)\end{array}$ & $\begin{array}{l}\text { SCOPUS* } \\
(25-6-2009)\end{array}$ & $\begin{array}{l}\text { EBSCO- } \\
\text { Greenfile* } \\
(26-6-2009)\end{array}$ & $\begin{array}{c}\text { CAB } \\
\text { Abstracts* } \\
(26-6-2009)\end{array}$ & $\begin{array}{l}\text { LILACS* } \\
(26-6-2009)\end{array}$ \\
\hline $\begin{array}{l}\text { "millennium development goals" OR } \\
\text { "MDG" AND "Environmental } \\
\text { sustainability" }\end{array}$ & 8 & 11 & 24 & 61 & 8 & 18 & 11 \\
\hline $\begin{array}{l}\text { "millennium development goals" OR } \\
\text { "MDG" AND "environmental policy" }\end{array}$ & 0 & 0 & 1 & 64 & 15 & 4 & 0 \\
\hline $\begin{array}{l}\text { "millennium development goals" OR } \\
\text { "MDG" AND "sustainable } \\
\text { development" }\end{array}$ & 13 & 8 & 45 & 171 & 28 & 30 & 8 \\
\hline $\begin{array}{l}\text { "millennium development goals" OR } \\
\text { "MDG" AND "biodiversity" }\end{array}$ & 4 & 3 & 13 & 22 & 8 & 16 & 3 \\
\hline $\begin{array}{l}\text { "millennium development goals" OR } \\
\text { "MDG" AND "water" AND } \\
\text { "sanitation" }\end{array}$ & 18 & 18 & 54 & 71 & 19 & 34 & 18 \\
\hline $\begin{array}{l}\text { "millennium development goals" OR } \\
\text { "MDG" AND "slums" }\end{array}$ & 5 & 6 & 14 & 20 & 5 & 4 & 6 \\
\hline TOTAL & 48 & 46 & 151 & 409 & 83 & 106 & 46 \\
\hline
\end{tabular}

"Water Policy" (International Water Association Publishing), "Environmental Science and Policy" (Elsevier). Finally, we searched for grey literature on the websites of prominent nongovernmental organisations: Global Footprint Network (Global Footprint Network, 2009), WWF international (WWF, 2009), Greenpeace international (Greenpeace, 2009); and other international organizations: United Nations Millennium Development Goals (UN, 2009), United Nations Development Program (UNDP, 2009), United Nations Environmental Program (UNEP, 2009).

\subsection{Data extraction}

We located 889 potential documents in the databases, of which 26 (2.9\%) were selected for examination in more detail. The first reviewer (LD) excluded 526 (59.1\%) repeated papers, $243(27.3 \%)$ reviews, $39(4.3 \%)$ conference papers, 46 (5.1\%) editorials, and 9 (1.01\%) papers in languages other than English or Spanish. No potentially included papers were identified in the other searches (reference section, hand-searched journals or grey literature).

The 26 studies selected for potential inclusion were independently appraised by two reviewers (LD and DG), and any disagreements solved by discussion. The following information was extracted from all studies that were finally included in the review: country in which the study took place, objective, design, sample population, data source, target or targets studied, indicators used, results, conclusions and recommendations. For those studies which identified barriers that could hinder the achievement of the MDG7, the information was extracted and shown in the conclusion section.

\subsection{Critical appraisal}

For the critical appraisal of the published studies we used criteria adapted from published systematic reviews (Bambra et al., 2008), electronic tools like the STROBE Statement (STROBE, 2009) and a proposed checklist for the critical analysis of cross-sectional studies (Berra et al., 2008) (Box 2).

\section{Results}

Of the 26 studies selected for potential inclusion, 20 (76.9\%) were excluded: 8 (40.0\%) addressed issues relevant to the MDG7 targets but did not make reference to the MDG strategy, 6 (30.0\%) analysed other MDGs, 3 (15.0\%) papers were econometric studies which set out to predict MDG progress, $2(10.0 \%)$ were interventions to improve the environment, and $1(5.0 \%)$ was a proposal of indicators to measure environmental factors. Finally, 6 (23.1\%) studies were included (Rehfuess et al., 2006; Mwendera, 2006; Gundry et al., 2006; DominguezAguilar and Garcia-de Fuentes, 2007; O'Hara et al., 2008; Martinez et al., 2008).

\subsection{Characteristics of studies}

Table 1 shows the main characteristics of the papers. Regarding the study design, there were two ecological studies

Box 2. Critical appraisal criteria.*

1. Is the study carried out in a representative sample population?

2. Does the study include an appropriate comparison group?

3 . Is the baseline response greater than $60 \%$ ?

4. Is there any adjustment for potential confounders?

5. Were appropriate statistical tests used?

6. Are any limitations to the study identified?

7. Does the study use a pre-validated outcome measure?

*Adapted from: Bambra et al. (2008), Berra et al. (2008) and Strobe Statement (2009). 
Table 1 - Characteristics of the studies systematically analysed which describe the progress of the Millennium Development Goal 7 or identify barriers which hinder its achievement.

\begin{tabular}{|c|c|c|c|c|c|c|c|c|c|}
\hline Author & Country & $\begin{array}{l}\text { Objective of } \\
\text { study }\end{array}$ & $\begin{array}{l}\text { Type of } \\
\text { study }\end{array}$ & Sample & $\begin{array}{l}\text { Data } \\
\text { source }\end{array}$ & $\begin{array}{l}\text { Target or } \\
\text { targets } \\
\text { studied }\end{array}$ & $\begin{array}{l}\text { Indicators } \\
\text { used }\end{array}$ & Results & $\begin{array}{l}\text { Conclusions (barriers } \\
\text { identified and future } \\
\text { recommendations) }\end{array}$ \\
\hline $\begin{array}{l}\text { Mwendera } \\
\text { (2006) }\end{array}$ & Swaziland & $\begin{array}{l}\text { Analyse the rural } \\
\text { water supply and } \\
\text { sanitation coverage } \\
\text { in Swaziland }\end{array}$ & $\begin{array}{l}\text { Descriptive } \\
\text { study }\end{array}$ & $\begin{array}{l}\text { Households } \\
\text { of Swaziland }\end{array}$ & National & Target 10 & $\begin{array}{l}\text { Proportion of population } \\
\text { with sustainable access } \\
\text { to an improved water } \\
\text { source (UN) } \\
\text { Proportion of } \\
\text { population with } \\
\text { access to improved } \\
\text { sanitation (UN) }\end{array}$ & $\begin{array}{l}\text { Rural water supplies } \\
\text { coverage increased } \\
56-60 \% \text { between } \\
2004 \text { and } 2005 \\
\text { Rural sanitation } \\
\text { increased from } 61 \% \\
\text { to } 63 \% \text { in } 2004 \\
\text { and } 2005 \\
\text { In } 2022 \text { coverage for } \\
\text { water and sanitation } \\
\text { will be } 100 \%\end{array}$ & $\begin{array}{l}\text { Increased funding from } \\
\text { government is needed } \\
\text { to achieve } 100 \% \text { coverage } \\
\text { of water and sanitation } \\
\text { There are serious } \\
\text { problems of structural } \\
\text { poverty and unequal } \\
\text { income distribution } \\
\text { in the country } \\
\text { There is a strong } \\
\text { need to get political will } \\
\text { to improve people lives }\end{array}$ \\
\hline $\begin{array}{l}\text { Gundry et al. } \\
(2006)\end{array}$ & $\begin{array}{l}\text { Zimbabwe } \\
\text { and South } \\
\text { Africa }\end{array}$ & $\begin{array}{l}\text { To assess } \\
\text { contamination of } \\
\text { drinking water in } \\
\text { rural areas of South } \\
\text { Africa and Zimbabwe }\end{array}$ & $\begin{array}{l}\text { Cohort } \\
\text { study }\end{array}$ & $\begin{array}{l}254 \text { children } \\
\text { aged } 12-24 \\
\text { months }\end{array}$ & National & Target 10 & $\begin{array}{l}\text { E. coli counts in } \\
\text { improved an } \\
\text { unimproved } \\
\text { water sources }\end{array}$ & $\begin{array}{l}\text { Improved sources } \\
\text { analysis: samples } \\
\text { with E. coli count } \\
\text { less than } 10 \mathrm{cfu} / 100 \mathrm{ml} \\
\text { were: at source } 165 \\
(88 \%) \text {; in household } \\
\text { storage } 137(59 \%) \text {; in } \\
\text { drinking cups } 91(49 \%) \\
\text { In unimproved } \\
\text { sources were: at } \\
\text { source } 47(29 \%) ; \\
\text { household storage } \\
32(19 \%) ; \text { drinking } \\
\text { cups } 21(18 \%)\end{array}$ & $\begin{array}{l}\text { In household storage, } \\
\text { more than } 40 \% \text { of } \\
\text { samples were "unsafe" } \\
\text { For the purposes of } \\
\text { MDG monitoring, the } \\
\text { assumption that an } \\
\text { improved source means } \\
\text { "safe water" is unrealistic }\end{array}$ \\
\hline $\begin{array}{l}\text { Rehfuess et al. } \\
\text { (2006) }\end{array}$ & $\begin{array}{l}\text { WHO } \\
\text { regions }\end{array}$ & $\begin{array}{l}\text { An assessment of } \\
\text { household solid fuel } \\
\text { use on a country-by- } \\
\text { country basis, and } \\
\text { implications for } \\
\text { achieving MDGs } \\
\text { at large }\end{array}$ & $\begin{array}{l}\text { Ecological } \\
\text { study }\end{array}$ & $\begin{array}{l}181 \text { countries } \\
\text { from WHO } \\
\text { regions }\end{array}$ & International & Target 9 & $\begin{array}{l}\text { Proportion of } \\
\text { population } \\
\text { using solid } \\
\text { fuels (UN) }\end{array}$ & $\begin{array}{l}\text { 77\% in Sub-Saharan } \\
\text { Africa } \\
\text { 16\% in Latin America } \\
\text { and Central and } \\
\text { eastern Europe } \\
\text { Less } 5 \% \text { in most } \\
\text { industrialized } \\
\text { countries }\end{array}$ & $\begin{array}{l}\text { Trends confirm that } \\
\text { "Proportion of population } \\
\text { using solid fuels" is } \\
\text { decreasing, but some } \\
\text { regions (Sub-Saharan } \\
\text { Africa) continue off-track } \\
\text { on achievement of MDGs } \\
\text { It is urgent to develop } \\
\text { agendas to include this } \\
\text { indicator in political } \\
\text { action }\end{array}$ \\
\hline
\end{tabular}




\begin{tabular}{|c|c|c|c|c|c|c|c|c|c|}
\hline $\begin{array}{l}\text { Dominguez-Aguilar } \\
\text { and Garcia-de } \\
\text { Fuentes (2007) }\end{array}$ & Mexico & $\begin{array}{l}\text { To discuss some } \\
\text { of the barriers } \\
\text { faced in Cancun } \\
\text { to achieve MDG7 } \\
\text { targets of water } \\
\text { and sanitation }\end{array}$ & $\begin{array}{l}\text { Descriptive } \\
\text { study }\end{array}$ & $\begin{array}{l}6 \text { zones from the } \\
\text { richer hotel zone } \\
\text { to the peri-urban } \\
\text { squatter } \\
\text { settlements which } \\
\text { represent } 485,346 \\
\text { inhabitants }\end{array}$ & National & Target 10 & $\begin{array}{l}\text { Proportion of population } \\
\text { with sustainable } \\
\text { access to an improved } \\
\text { water source (UN) } \\
\text { Proportion of population } \\
\text { with access to improved } \\
\text { sanitation (UN) }\end{array}$ & $\begin{array}{l}4 \text { of the } 6 \text { zones had } \\
\text { access to a safe } \\
\text { drinking water } \\
2 \text { of } 6 \text { had access } \\
\text { to an improved } \\
\text { sanitation }\end{array}$ & $\begin{array}{l}\text { The socioeconomic } \\
\text { disparities produced by } \\
\text { market forces, and } \\
\text { reinforced by government } \\
\text { policies, mean that the } \\
\text { richest have better access } \\
\text { than the poorest to safe } \\
\text { water and sanitation } \\
\text { Failure of State Drinking } \\
\text { and Sanitation Law, for } \\
\text { economic and political } \\
\text { factors } \\
\text { The lack of concern } \\
\text { shown by social actors } \\
\text { to aquifer contamination } \\
\text { Cancun government } \\
\text { needs to act to } \\
\text { achieve MDG water and } \\
\text { sanitation at local level }\end{array}$ \\
\hline $\begin{array}{l}\text { Martinez et al. } \\
\text { (2008) }\end{array}$ & $\begin{array}{l} \\
\text { South-eastern } \\
\text { Asia } \\
\text { Southern Asia } \\
\text { Sub-Saharan } \\
\text { Africa } \\
\text { Western Asia }\end{array}$ & $\begin{array}{l}\text { To analyse the } \\
\text { trends in the } \\
\text { living } \\
\text { conditions of } \\
\text { slum and } \\
\text { non-slum } \\
\text { populations } \\
\text { over the } \\
\text { period } \\
\text { 1990-2003 }\end{array}$ & $\begin{array}{l}\text { Ecological } \\
\text { study }\end{array}$ & $\begin{array}{l}188 \text { cities of the } \\
8 \text { millennium } \\
\text { development } \\
\text { regions }\end{array}$ & International & Target 11 & $\begin{array}{l}\text { Proportion of population } \\
\text { with sustainable access } \\
\text { to an improved water } \\
\text { source (UN) } \\
\text { Proportion of population } \\
\text { with access to improved } \\
\text { sanitation (UN) }\end{array}$ & $\begin{array}{l}\text { Median access remains } \\
\text { above } 90 \% \text { through } \\
\text { alternative water } \\
\text { sources } \\
\text { Median connection to } \\
\text { piped water rose } \\
\text { from } 56 \% \text { to } 65 \% \\
\text { (1990-2003) } \\
\text { Median percentage } \\
\text { connection to sewers } \\
\text { increased from } 44 \% \\
\text { to } 70 \% \text { (1990-2003), } \\
\text { Sub-Saharan Africa } \\
\text { had a median of } 13 \%\end{array}$ & $\begin{array}{l}\text { There is a general } \\
\text { improvement in various } \\
\text { shelter and quality life } \\
\text { conditions } \\
\text { In most sub-Saharan } \\
\text { African countries, } \\
\text { there was an increase } \\
\text { in inequalities } \\
\text { Growth of peri-urban } \\
\text { settlements has } \\
\text { signified the need of } \\
\text { urban development } \\
\text { programmes to improve } \\
\text { living conditions } \\
\text { Issues of urban } \\
\text { development and } \\
\text { poverty such as social } \\
\text { exclusion, and regional } \\
\text { differences are not } \\
\text { reflected in the } \\
\text { indicators }\end{array}$ \\
\hline
\end{tabular}




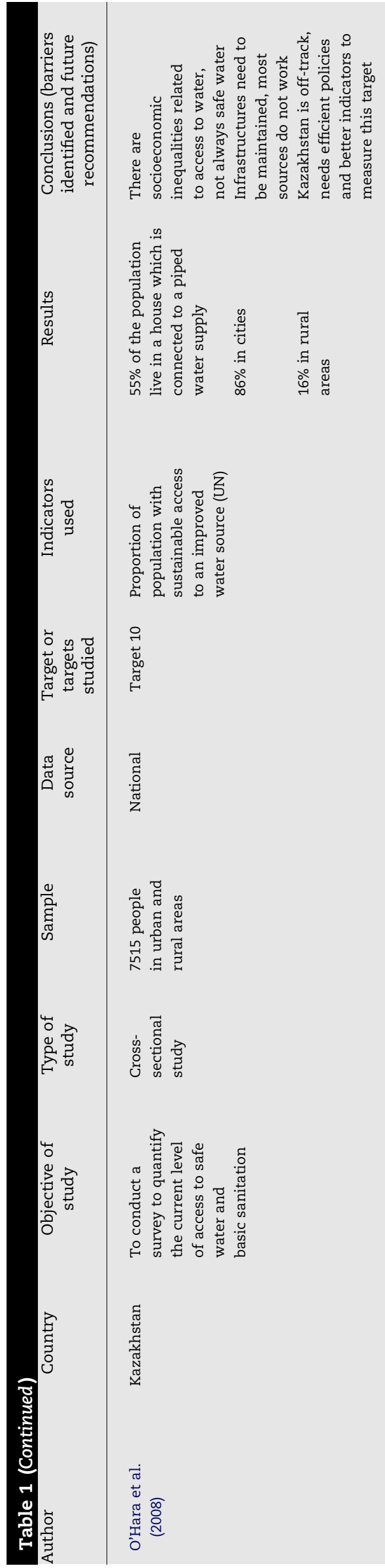

(Rehfuess et al., 2006; Martinez et al., 2008), two descriptive studies (Mwendera, 2006; Dominguez-Aguilar and Garcia-de Fuentes, 2007), one cohort study (Gundry et al., 2006), and one cross-sectional study (O'Hara et al., 2008). The sample populations studied were highly heterogeneous: one study analysed 254 children (Gundry et al., 2006), while another studied 188 countries from WHO regions (Rehfuess et al., 2006).

The data sources used for analysis were national data in four studies (Dominguez-Aguilar and Garcia-de Fuentes, 2007; Mwendera, 2006; Gundry et al., 2006; O'Hara et al., 2008) and international data in the other two studies (Rehfuess et al., 2006; Martinez et al., 2008).

The most studied MDG7 target was Target 10: "To halve, by 2015 , the proportion of people without sustainable access to safe drinking water and basic sanitation". It was the objective of study in four papers (Dominguez-Aguilar and Garcia-de Fuentes, 2007; Mwendera, 2006; Gundry et al., 2006; O’Hara et al., 2008). One study analysed Target 9: "To integrate the principles of sustainable development into country policies and programmes and reverse the loss of environmental resources" (Rehfuess et al., 2006), and one study analysed Target 11: "By 2020, to have achieved a significant improvement in the lives of at least 100 million slum dwellers" (Martinez et al., 2008).

To measure the situation of MDG7, 5 of the studies used indicators defined by the United Nations, such as: "Proportion of population with sustainable access to an improved water source" or "proportion of population with access to improved sanitation" (Dominguez-Aguilar and Garcia-de Fuentes, 2007; Mwendera, 2006; Gundry et al., 2006; O'Hara et al., 2008; Rehfuess et al., 2006). One study (Gundry et al., 2006) used a microbiological indicator: "Escherichia coli counts in $100 \mathrm{ml}$ of water"

The main results, conclusions and recommendations of the studies were analysed.

\section{- Analysis of Target 9:}

An ecological study (Rehfuess et al., 2006) which analysed household solid fuel use in the WHO regions showed that $52 \%$ of the world's population still uses solid fuels. The most extensive use was in the Sub-Saharan Africa region (77\%), while in industrialized countries solid fuel uses was under $5 \%$ of the population.

\section{- Analysis of Target 10 :}

One study (Mwendera, 2006) described the situation of Swaziland's water and sanitation coverage. The analysis showed slow improvement in both indicators $(56-60 \%$ in 2004-2005 for water supplies, and 61-63\% in 2004-2005 for basic sanitation), and expressed an expectation of reaching $100 \%$ of coverage by 2022 . To reach this target the government would need to increase funding and develop a plan to solve the serious problem of structural poverty and income inequality in Swaziland.

Another descriptive study (Dominguez-Aguilar and Garciade Fuentes, 2007) was carried out in Cancun city (Mexico). The authors carried out an analysis of the access to safe drinking 
water and basic sanitation in order to identify the barriers which prevent the city from achieving Target 10 . They divided Cancun in six zones (ranging from a rich hotel area to periurban settlements) and observed that only four of six zones had access to safe drinking water, and only two had access to improved sanitation.

The cohort study (Gundry et al., 2006) explored the contamination of drinking water in rural areas. They studies both improved water sources and unimproved water sources and took a sample of water to measure how much E. coli was present. Unimproved sources had a higher number of E. coli than was expected, but improved sources also had E. coli. They concluded that populations that have access to improved sources of water do not always have access to "safe water".

The cross-sectional study (O'Hara et al., 2008) estimated the level of access to safe water of the urban and rural population of Kazakhstan. Over $55 \%$ of people had a piped water supply in their home, but there was a great difference between cities and rural areas ( $86 \%$ vs. $16 \%$ ). There were a high number of sources which were deteriorated, most of them in rural areas; this situation may lead to "unsafe" water from piped water supplies.

\section{- Analysis from Target 11:}

Another ecological study (Martinez et al., 2008) described the trend of slum dwellers during the period 1990-2003. The results were positive as an improvement was observed in most Millennium Development regions; most reach $90 \%$ access by using alternative supply systems. Access to piped water rose from $56 \%$ to $65 \%$ in the period $1990-2003$, and basic sanitation increased from $44 \%$ to $70 \%$ in the same period. Nevertheless, sub-optimal access to safe water and basic sanitation persisted in the cities of Sub-Saharan Africa during this period.

Among the studies which identified barriers to achieving MDG7 or any of its targets, the most frequent were socioeconomic inequalities (Mwendera, 2006; Dominguez-Aguilar and Garcia-de Fuentes, 2007; O'Hara et al., 2008), the deterioration of infrastructure providing access to water and basic sanitation due to the lack of economic investments (O'Hara et al., 2008; Gundry et al., 2006; Mwendera, 2006), the contamination of water sources (Gundry et al., 2006; Dominguez-Aguilar and Garcia-de Fuentes, 2007), and the lack of political will (Dominguez-Aguilar and Garcia-de Fuentes, 2007).

\subsection{Critical appraisal results}

The results of the critical appraisal can be seen in Table 2. Five of the six studies were considered to have a representative sample. One study (O'Hara et al., 2008) had a small sample which was not considered to be representative. None of the studies used a comparison group in its methodological design.

In four of the six studies, the baseline response was greater than $60 \%$. Only the cohort study (Gundry et al., 2006) made an adjustment for potential confounders. All of the studies used statistical tests considered appropriate for their designs. Three papers identified potential limitations of their studies: one study (Martinez et al., 2008) declared that most of the analyses were carried out on a particular proportion of the city which may limit the external validity of the data; while another
(Rehfuess et al., 2006) stated that there were limitations related to data extraction and estimation methods. The crosssectional study (O'Hara et al., 2008) declared that the small study sample was a limitation. All studies used validated measures; most of them were United Nations indicators established to measure the progress of the Millennium Development Goals (i.e. \% of population with access to safe drinking water).

\section{Discussion}

Scientific knowledge concerning the progress of MDG7 and analysing the obstacles that could hinder its achievement is essential to help these environmental agreements move forward. Only six empirical studies which provide information about this issue were identified in our review. The studies affirm that the progress of the MDG7 is limited at international, national and local level. The studies were highly heterogeneous in terms of theoretical frameworks, objectives, and methods, including samples and designs. Furthermore, this heterogeneity implies problems in the quality analysis of the studies.

The situation of MDG7 must be improved in order to accomplish the objectives (UN, 2009), and new information about the determinants of non-attainment are needed. In our review, we identified socioeconomic inequalities, lack of proper infrastructure and deficient management, lack of political will at the local level, and contamination of the sources assigned to provide water to the population as the main barriers which hinder the progress of MDG7. This information is relevant in terms of political action, especially at the local and national level, and helps to build new policies to avoid obstacles of its achievement.

We only found one review regarding MDG progress (PalmaSolis et al., 2009a,b) in which political and economic factors were identified as barriers. These barriers were also identified in our research. We know that an increasing amount of knowledge exists around other MDG. For instance, Fotso et al. (2007) analyse how urban growth, access to drinking water and vaccination coverage affect progress towards MDG 4 in SubSaharan Africa. Palma-Solis et al. (2009a,b) analysed policy determinants of the MDG1 (hunger and poverty), identifying government consumption as a barrier to achieve MDG1. Furthermore, Houweling et al. (2007) propose research to demonstrate how socioeconomic inequalities in maternity care affect Goal 5 (reduction in maternal mortality). We identified less information for MDG7 than for the other MDGs. However, scientific knowledge is fundamental for the design of further interventions to achieve the Millennium Development Goals (Tugwell et al., 2006) and could identify structural or social problems that prevent the achievement of this macro agreement and future agreements.

A large scale international agreement on the environment such as the Rio de Janeiro (UN, 1992) declaration on environment and development, which laid the foundations for action against what was then an emerging problem, and the Kyoto Protocol (UNFCC, 1997) for the reduction of contaminating gases, failed to achieve the targets set out. It would seem that MDG7 will go the same way. Despite the 
Table 2 - Critical appraisal of studies which describe the progress of the Millennium Development Goal 7 or analyse the barriers that would hinder their achievement.

Is the study carried out Does the study $\quad$ Is the baseline $\quad$ Is there any $\quad$ Were appropriate Are any limitations to Does the study use a in a representative include an appro response adjustment for statistical tests the study identified? pre-validated outcome sample population? priate comparison greater potential $\begin{array}{ccc}\text { priate comparison } & \text { greater } & \text { potential } \\ \text { group? } & \text { than } 60 \% \text { ? } & \text { confounders? }\end{array}$ measure?

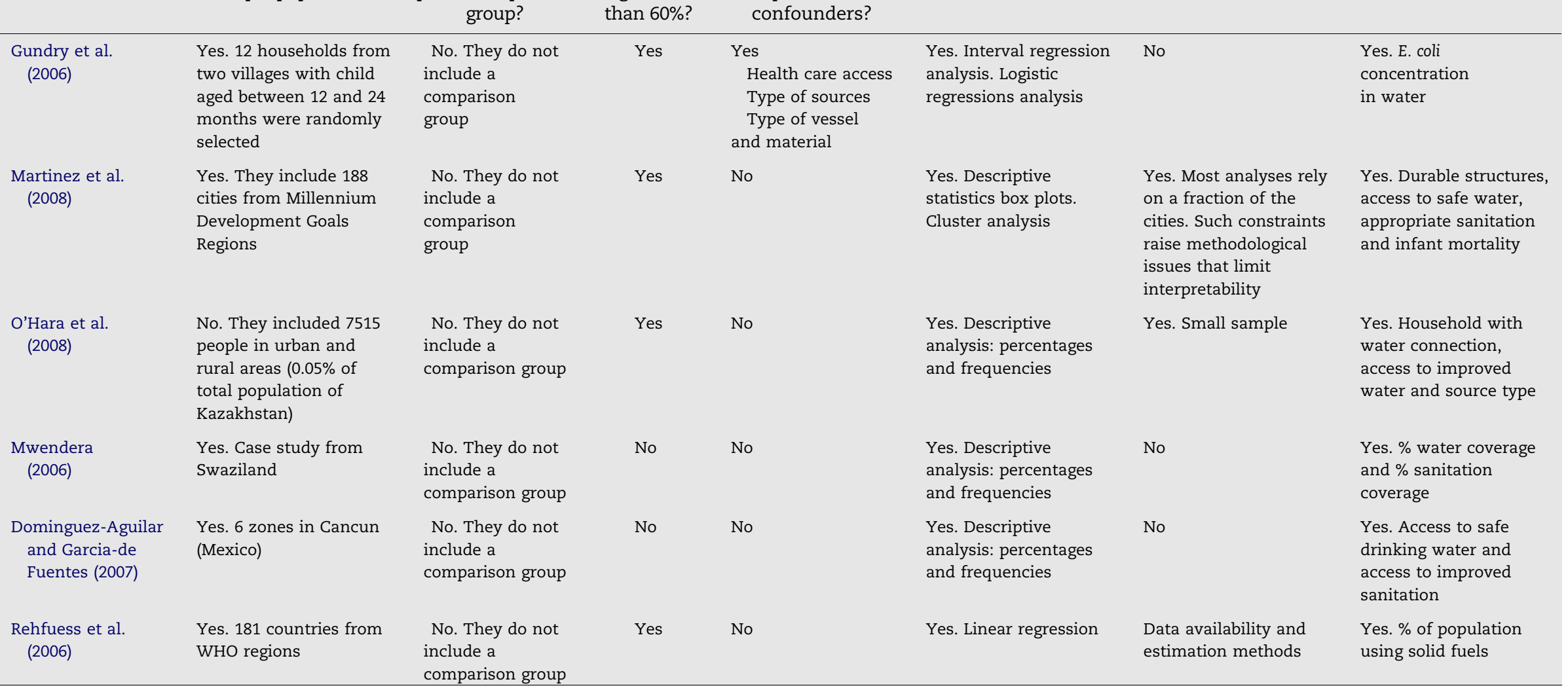


importance of ensuring environmental sustainability of population health and welfare (McMichael et al., 2008), the environmental issue do not seem to be a priority in research and political agendas, while the international organisations continue to insist that the objective is extremely important (Sachs and McArthur, 2005; Jolly, 2004) and urge countries to persevere.

A discipline like political epidemiology could play a key role in the identification of political determinants which affect social factors and progress of MDGs, and in the proposal of future public policies to improve the achievement of targets. With MDGs, the UN applies a model comprised of wishful thinking, opinion, and good intentions that is limited by the lack of a solid scientific base, given the dearth of scientific information concerning the health implications of political initiatives (Gil-González et al., 2009).

We encountered limitations when carrying out this systematic review. The first of these was the small sample of studies, their heterogenic characteristics, and the fact that they are studies which came from different disciplines like urbanism, environment, health, and development. In addition, all of the studies expressed their results in a particular form. We also had difficulties extracting data and comparing results between papers with different designs, which in most cases only permitted a descriptive analysis of their results. Finally, knowledge relevant for the MDGs may be generated in many contexts; e.g., by scientists unaware of MDGs or by institutions with no interest in MDGs, but we limited our research to knowledge generated around MDG7 through empirical studies published in scientific journals and grey literature from different organizations.

In the current framework of climate change, it is essential to implement policies for sustainable development and preservation of natural resources, the use of renewable, clean energy (Haines et al., 2007), and sustainable urban development. These may provide the definitive push towards the environmental goal, and could enhance the situation of the health and education targets (McMichael et al., 2008; Bartram et al., 2005). Furthermore, it is important to create a space for reflection (James, 2006; Anand, 2007; Bass et al., 2006) which would enable a detailed review of the weak points (Murray, 2007) of the indicators for measuring progress, in order to adapt them to the new challenges of the environment.

\section{REFEREN C ES}

Agénor, P.R., Bayraktar, N., Moreira, E.P., El Aynaoui, K., 2006. Achieving the Millennium Development Goals in SubSaharan Africa: a macroeconomic monitoring framework. The World Economy 29, 1519-1547.

Anand, P.B., 2007. Semantic of success or pragmatic progress: an assessment of India's progress with drinking water supply. Journal of Environmental Development 16, 32-57.

Anyangwe, S., Mtonga, C., Chirwa, B., 2006. Health inequities, environmental insecurity and the attainment of Millennium Development Goals in Sub-Saharan Africa: the case study of Zambia. International Journal of Environmental Research and Public Health 3, 217-227.

Bambra, C., Whitehead, M., Swoden, A., Ackers, J., Petticrew, M., 2008. "A hard day's night?" The effects of Compressed
Working Week interventions on the health and work-life balance of shift workers: a systematic review. Journal of Epidemiology and Community Health 62, 764-777.

Bartram, J., Lewis, K., Lenton, R., Wright, A., 2005. Focusing on improved water and sanitation for health. Lancet 365, 810812.

Bass, S., Bigg, T., Bishop, J., Tunstall, D., 2006. Sustaining the environment to flight poverty and achieve the Millennium Development Goals. Review of European Community \& International Environmental Law 15, 39-55.

Berra, S., Elorza-Ricart, J.M., Estrada, M.D., Sánchez, E., 2008. Instrumento para la lectura crítica y la evaluación de estudios epidemiológicos transversales. Gaceta Sanitaria 22, 492-497.

Chakravarty, S.R., Majumder, A., 2008. Millennium Development Goals: measuring progress towards their achievement. Journal of Human Development 9, 109-129.

Dahlgren, G., Whitehead, M., 2007. European strategies for tackling social inequities in health: levelling up. WHO Regional Office for Europe. Available from: http:// euro.who.int/document/e89384.pdf [accessed October 20, 2009].

Dominguez-Aguilar, M., Garcia-de Fuentes, A., 2007. Barriers to achieving the water and sanitation-related Millennium Development Goals in Cancún, Mexico at the beginning of the twenty-first century. Environment \& Urbanization 19, 243-260.

Fotso, J.C., Chika, A., Madise, N., Ciera, J., 2007. Progress towards the child mortality Millennium Development Goal in SubSaharan Africa: the dynamics of population growth, immunization, and access to clean water. BMC Public Health, doi:10.1186/1471-2458-7-218.

Gil-González, D., Carrasco-Portiño, M., Davó Blanes, M.C., Donat Castelló, L., Franco-Giraldo, A., Ortiz Moncada, R., et al., 2008. Valoración de los objetivos de desarrollo del milenio mediante la revisión de la literatura científica en 2008. Revista Española de Salud Publica 82, 455-466.

Gil-González, D., Cantero, M.T., Alvarez-Dardet, C., 2009. How political epidemiology can address why the Millennium Development Goals have not been achieved: developing a research agenda. Journal of Epidemiology and Community Health 63, 278-280.

Global Footprint Network, 2009. Ecological Footprint [Online]. Available from: http://www.footprintnetwork.org [accessed September 2, 2009].

Greenpeace, 2009. Greenpeace International [Online]. Available from: http://www.greenpeace.org [accessed September 3, 2009].

Gundry, S., Wright, J., Conroy, R., Du Preez, M., Genthe, B., Moyo, S., et al., 2006. Contamination of drinking water between source and point-of-use in rural household of South Africa and Zimbabwe: implications for monitoring the Millennium Development Goal for water. Water Practice \& Technology, doi:10.2166/WPT.2006032.

Haines, A., Smith, K.R., Anderson, D., Epstein, P.R., McMichael, A.J., Roberts, I., et al., 2007. Policies for accelerating access to clean energy, improving health, advancing development, and mitigating climate change. Lancet 370, 1264-1281.

Houweling, T., Ronsmans, C., Campbell, O., Kunst, A., 2007. Huge poor-rich inequalities in maternity care: an international comparative study of maternity and child care in developing countries. Bulletin of World Health Organization 85, 745-754.

James, J., 2006. Misguised investments in meeting Millennium Development Goals: a reconsideration using ende-based targets. Third World Quarterly 27, 443-458.

Jolly, R., 2004. Misguised investments in meeting Millennium Development Goals: a consideration using ende-based targets. Third World Quarterly 27, 443-458. 
Martinez, J., Mboup, G., Sulizas, R., Stein, A., 2008. Trends in urban and slum indicators across developing world cities, 1990-2003. Habitat International 32, 86-108.

McMichael, A.J., Butler, C.D., Folke, C., 2003. New visions for addressing sustainability. Science 302, 1919-1920.

McMichael, A.J., Butler, C.D., 2006. Emerging health issues: the widening challenge for population health promotion. Health Promotion International 21, 15-24.

McMichael, A.J., Nyong, A., Corvalan, C., 2008. Global environmental change and health: impacts, inequalities, and the health sector. British Medical Journal 336, 191-194.

Melnick, D.J., Navarro, Y.K., McNeely, J., Schmidt-Traub, G., Sears, R.R., 2005. The Millennium Project: the positive health implications of improved environmental sustainability. Lancet $365,723-725$.

Murray, C.J., 2007. Towards good practice for health statistics: lessons from the Millennium Development Goal health indicators. Lancet 369, 862-873.

Mwendera, E., 2006. Rural water supply and sanitation (RWSS) coverage in Swaziland: toward achieving Millennium Development Goals. Physics and Chemistry of the Earth 31, 681-689.

O'Hara, S., Hannan, T., Genina, M., 2008. Assessing access to safe water and monitoring progress on MDG7 Target 10 (access to safe water and basic sanitation): lessons from Kazakhstan. Water Policy 10, 1-24.

Palma-Solis, M., Hernandez-Aguado, I., Gil-González, D., Ruiz, M.T., Medina, M., 2009a. Factores económicos relacionados con los Objetivos de Desarrollo del Milenio de salud: una revisión sistemática. Revista Panamericana de Salud Pública 26, 161-171.

Palma-Solis, M., Alvarez-Dardet, C., Ruiz, M.T., 2009b. Policy determinants affecting the hunger Millennium Development Goal. Social Science \& Medicine 68, 1788-1792.

Prüss, A., Kay, D., Fewtrell, L., Bartram, J., 2002. Estimating the burden of disease from water, sanitation, and hygiene at global level. Environmental Health Perspectives 110, 537542.

Rehfuess, E., Metha, S., Pruss-Ustun, A., 2006. Assessing household solid fuel use: multiple implications for the Millennium Development Goals. Environmental Health Perspectives 114, 373-378.

Sachs, J.D., McArthur, J.W., 2005. The Millennium Project: a plan for meeting the Millennium Development Goals. Lancet 365, 347-353.

Sachs, Reid., 2006. Invest towards sustainable development. Science 312, 1002.

Sahn, D., Stifel, D., 2003. Progress toward the millennium development in Africa. World Development 31, 23-52.

Satterthwaite, D., 2003. Millennium Development Goals and urban poverty reduction: great expectations, nonsense statistics. Environment \& Urbanization 15, 181-190.

Strobe Statement, 2009. Strobe Checklists [Online]. Available from: http://www.strobe-statement.org [accessed September 14, 2009].

Tugwell, P., Robinson, V., Grimshaw, J., Santesso, N., 2006. Systematic reviews and knowledge translation. Bulletin of World Health Organization 84, 643-651.

United Nations, 2000a. The Millennium Declaration (Spanish version) [Online]. Available from: http://www.un.org/ spanish/millenniumgoals/background.html [accessed February 21, 2009].
United Nations, 2000b. Millennium Development Goals Indicators (Spanish version) [Online]. Available from: http:// mdgs.un.org/unsd/mdg/Home.aspx [accessed February 21, 2009].

United Nations Framework Convention on Climatic Change, 1997. The Kyoto Protocol [Online]. Available from: http:// unfccc.int/kyoto_protocol/items/2830.php [accessed March $4,2009]$.

United Nations, 1992. Report of the United Nations Conference on Environment and Development [Online]. Available from: http://www.un.org/documents/ga/conf151/aconf151261annex1.htm [accessed March 4, 2009].

United Nations, 2009. Millennium Development Goals Report 2009 (Spanish version) [Online]. Available from: http:// www.un.org/spanish/millenniumgoals/documents.html [accessed March 4, 2009].

United Nations Development Programme, 2005. Los Objetivos de Desarrollo del Milenio [Online]. Available from: http:// www.undp.org/spanish/mdg/basics.shtml [accessed February 21, 2009].

United Nations Environmental Programme, 2009. Millennium Development Goal 7 [Online]. Available from: http:// www.unep.org [accessed September 4, 2009].

Varis, O., 2006. Megacities, development and water. Water Resources Development 22, 199-225.

Varis, O., 2007. Right to water: the Millennium Development Goals and the MENA region. International Journal of Water Resources Development 23, 243-266.

World Wildlife Fund, 2009. WWF International [Online]. Available from: http://www.panda.org [accessed September 3, 2009].

Lucas Donat Castelló has been a Researcher in Public Health at the University Miguel Hernandez (Alicante) and CIBERESP (Centro de Investigacion Biomedica en Red de Epidemilogia y Salud Pública) since 2007. He gained a Master's degree in Public Health from University Miguel Hernandez (Alicante) in 2008.

Diana Gil-González is Senior Lecturer in Public Health in the University of Alicante (Spain) and memeber of the Observatory of Public Policies and Health. He has a PhD in Sociology and experience in research and teaching in social determinants of health including migration, discrimination, intimate partner violence, and in health policies.

Carlos Alvarez-Dardet Diaz, MD, PhD, MFPH is Professor of Public Health and Preventive Medicine at the University of Alicante and Director of the Observatory of Public Policies and Health. He has been Editor in Chief of the Journal of Epidemiology and Community Health (1998-2008), President of the European Public Health Association (1994-1997), President of the Spanish Public Health Association (1990-1994) and has published more than 120 social epidemiology papers and several books.

Ildefonso Hernández-Aguado, $\mathrm{MD}, \mathrm{PhD}$ is Professor of Public Health at the University Miguel Hernández (Alicante) and has been Chief Medical Officer of the Spanish Government from May 2008. He was Deputy Editor of the Journal of Epidemiology and Community Health (1997-2008) and President of the Spanish Epidemiological Association (2003-2006). He has published more than 120 papers and several books. 